\title{
KAJIAN PARTISIPASI PEREMPUAN PADA PEREKONOMIAN KELUARGA DI KAMPUNG PELANGI RANDUSARI
}

\author{
Marya Tisnandya ${ }^{1}$ \\ Landung Esariti \\ Mada Sophianingrum ${ }^{3}$ \\ Departemen Perencanaan Wilayah dan Kota, Fakultas Teknik, Universitas Diponegoro 1,2,3 \\ Penulis Korespondensi e-mail: landungesariti@lecturer.undip.ac.id
}

\begin{abstract}
The objective of this study is to analyze the forms and the most influential factors of women's participation in the family economy of Kampung Pelangi Randusari. Women's participation activities are conducted via the provision of skills training and increased involvement in the formation of home based enterprises. By using quantitative methods, this article applied scoring and weighting analysis tool. Data collection was conducted by delivering questionnaires and interviews with 30 respondents of married couples. The results of this study indicate that the largest participation of women in the family economy is in the form of participation in labour, money, and individual asset. In addition, the most influential factor is the ability to optimally elaborate skills derived from training activities and the ability to manage home based enterprises in order to improve family welfare.

Keywords: participation form, women participation, family economy
\end{abstract}

\section{ABSTRAK}

Penelitian ini bertujuan untuk menganalisis bentuk dan faktor yang mempengaruhi partisipasi perempuan pada perekonomian keluarga di Kampung Pelangi Randusari. Kegiatan partisipasi perempuan dilakukan melalui pengadaan pelatihan keterampilan dan peningkatan keterlibatan pada pembentukan usaha mikro atau UMKM. Dengan menggunakan metode kuantitatif melalui alat analisis skoring dan pembobotan, pengumpulan data dilakukan melalui kuesioner dan wawancara terhadap 30 responden pasangan suami istri. Hasil dari penelitian ini menunjukkan bahwa partisipasi perempuan pada ekonomi keluarga paling besar dilakukan dalam bentuk partisipasi tenaga, uang, dan harta benda.Sedangkan faktor yang paling berpengaruh adalah faktor kemampuan untuk memanfaatkan hasil pelatihan dan mengelola usaha mikro yang bertujuan untuk meningkatkan kesejahteraan keluarga.

Kata Kunci: bentuk partisipasi, ekonomi keluarga, partisipasi perempuan 


\section{PENDAHULUAN}

Sesuai dengan Permendagri tentang Pelaksanaan Pengarusutamaan Gender (PUG) tahun 2011, pemerintah daerah memiliki kewajiban untuk menyusun program dan kegiatan yang ramah dan responsif gender. Program tersebut termuat dalam Rencana Aksi Daerah (RANDA) yang meliputi PUG pada peraturan perundangan, PUG pada pembangunan, PUG pada kelembagaan, dan penguatan peran serta masyarakat di daerah. PUG pada penguatan peran serta masyarakat di daerah berkaitan dengan akses, partisipasi, kontrol dan perolehan manfaat atas keseimbangan fungsi dan peran perempuan pada kegiatan ekonomi.

Usaha tersebut dimaksimalkan oleh Pemerintah Kota Semarang melalui program kampung tematik yang menggunakan pendekatan bottom-up untuk melibatkan masyarakat setempat. Keterlibatan aktif masyarakat tidak hanya berdampak pada keberhasilan program namun juga pada peningkatan ekonomi keluarga. Salah satu contoh program kampung tematik yang ada di Kota Semarang merupakan Kampung Pelangi Randusari. Pendekatan pemberdayaan masyarakat yang digunakan di Kampung Pelangi merupakan pendekatan bottom-up yang difokuskan pada perempuan di Kampung Pelangi dengan pemberdayaan kelompok masyarakat (Suharto, 2005).. Kegiatan tersebut dilakukan melalui pelatihan dan pembentukan kelompok untuk meningkatkan kesadaran perempuan. Program ini bertujuan untuk meningkatkan jiwa kewirausahaan dan pembentukan usaha mikro atau UMKM. Sehingga, pelaksanaan kegiatan terarah dan sesuai tujuan agar kelompok perempuan di Kampung Pelangi dapat memulai usaha rumah tangga untuk membantu perekonomian keluarga.

Sumodiningrat (dalam Aryani, 2017) mengatakan, ekonomi keluarga merupakan bentuk kegiatan dan upaya keluarga untuk memenuhi kebutuhan dasar hidup (basic need) meliputi sandang, pangan, papan, kesehatan dan pendidikan. Bentuk partisipasi perempuan dalam ekonomi keluarga diartikan sebagai usaha untuk menghasilkan, mengelola, dan menyeimbangkan pendapatan untuk dapat memenuhi kebutuhan keluarga (Mohyuddin, 2014). Melalui penelitian yang dilakukan Mohyuddin (2014) menyimpulkan bahwa perempuan yang berpartisipasi dalam ekonomi keluarga memiliki kecenderungan untuk dapat mengelola kebutuhan dengan baik dan memiliki kemampuan untuk menyeimbangkan kegiatan domestik dan publik dengan baik.

Menurut Aswiyati (2016) partisipasi perempuan diperlukan dalam ekonomi keluarga sebagai upaya pengentasan kemiskinan dan peningkatan status perempuan dalam 
pengambilan keputusan dalam keluarga. Kontribusi perempuan dalam ekonomi rumah tangga akan menghasilkan peningkatan pendapatan rumah tangga, peningkatan kepemilikan barang mewah, dan peningkatan standar hidup melalui pencapaian, sehingga berdampak pada kesejahteraan keluarga (Lasswell dalam Puspitasari, 2013). Penelitian yang dilakukan oleh Freguja (2007) menyimpulkan bahwa pendapatan ekonomi keluarga tradisional, dengan hanya ayah yang menghasilkan pendapatan, memiliki kesejahteraan dan kualitas hidup yang lebih rendah dibandingkan dengan keluarga dengan istri yang ikut bekerja. Dukungan perempuan di Kampung Pelangi dalam ekonomi keluarga dilakukan dalam bentuk pembukaan usaha mikro yang dibantu oleh Pemerintah Kota Semarang bersama dengan Ikatan Arsitek Indonesia (Cahyaningrum, 2018).

Berdasarkan penjabaran tersebut, diketahui bahwa dukungan Pemerintah Kota Semarang terhadap peningkatan partisipasi perempuan melalui pendekatan bottom-up memberikan dorongan dan kesempatan bagi perempuan untuk berpartisipasi dalam ekonomi keluarga. Pelatihan dan pemberdayaan yang dilakukan mengangkat potensi dan memberi kesempatan perempuan untuk berwirausaha melalui usaha rumah tangga. Artikel ini bertujuan untuk mengkaji bentuk partisipasi perempuan dan faktor yang mempengaruhi partisipasi perempuan dalam kegiatan peningkatan ekonomi keluarga. Hal ini penting mengingat program pemberdayaan ekonomi keluarga yang dilakukan oleh kelompok perempuan merupakan salah satu indikator ketercapaian program pengentasan kemiskinan yang responsif gender, sesuai amanat RPJMD Kota Semarang.

\section{METODE PENELITIAN}

Subjek penelitian merupakan perempuan dan laki-laki dengan kriteria berstatus menikah di RW 03 Kelurahan Randusari. Sampel penelitian merupakan 30 pasang suami dan istri dengan status menikah. Sedangkan, teknik pengambilan sampel penelitian merupakan purposie sampling sebagai metode untuk memilih, mengidentifikasi, dan mengambil sampel sumber data dengan pertimbangan tertentu (Sugiyono, 2011). Metode analisis yang dipilih adalah metode kuantitatif dengan aplikasi analisis statistik deskriptif terhadap pengolahan data hasil dari kuesioner dan wawancara. Analisis selanjutnya menggunakan alat analisis skoring dan pembobotan, dengan rumus sebagai berikut:

\section{Rumus Mencari Skor Ideal Aspek Kuesioner}

(Skor tertinggi tiap butir instrumen) $x$ (Jumlah instrumen tiap aspek) $x$ (jumlah responden) Sumber: Sugiyono, 2013: 418 
Kajian partisipasi perempuan yang dianalisis pada artikel ini meliputi 2 pokok pembahasan, yaitu a). bentuk partisipasi perempuan dan b). faktor yang mempengaruhi kegiatan partisipasi perempuan. Partisipasi didefinisikan sebagai usaha untuk turut berperan dalam suatu kegiatan, keikutsertaan dalam kegiatan, peran aktif atau proaktif dalam kegiatan (Ramdani, 2015). Partisipasi perempuan pada perekonomian difokuskan pemerintah dengan memperluas kesempatan kerja, menyesuaikan gaji, mendorong fleksibilitas pasar tenaga kerja, meningkatkan keterampilan dan kapasitas perempuan melalui pelatihan, dan implementasi kebijakan yang berkaitan dengan keseteraan gender (KEMENKO PMK, 2019). Menurut Holil (dalam Deviyanti, 2013), terdapat beberapa bentuk partisipasi pada perekonomian, yaitu:

1) Partisipasi uang, yaitu bentuk partisipasi dalam rangka memperlancar usaha untuk mencapai kebutuhan masyarakat. Partisipasi berupa pemberian uang dapat dilakukan oleh sebagian atau seluruh anggota masyarakat.

2) Partisipasi harta benda, yaitu bentuk partisipasi yang diberikan berupa benda alat atau perkakas yang ditujukan untuk menunjang usaha yang dilakukan.

3) Partisipasi tenaga, yaitu bentuk partisipasi yang diberikan dalam bentuk tenaga untuk melakukan usaha-usaha dalam menunjang keberhasilan program.

Faktor yang mempengaruhi partisipasi diartikan sebagai alasan individu atau kelompok dalam memainkan peran pada program atau kebijakan (Rahmawati \& Sumarti, 2011). Partisipasi masyarakat dalam pembangunan dipengaruhi oleh faktor yang bersifat internal yang bersifat mendukung capaian suatu program (Suroso, 2014). Berikut merupakan faktor internal partisipasi (Slamet, 2003):

a) Kemauan, merupakan hal dari dalam diri yang menumbuhkan sikap dan minat masyarakat untuk dapat berpartisipasi.

b) Kemampuan, merupakan kesadaran atau keyakinan pada diri berupa pikiran, tenaga, waktu, sarana, atau material lain yang menjadi potensi yang dimiliki individu atau kelompok dalam masyarakat.

c) Kesempatan, merupakan kondisi lingkungan yang mendukung masyarakat dan menjadi peluang untuk berpartisipasi.

Untuk menilai mana faktor yang paling berpengaruh, maka dilakukan skoring terhadap jawaban responden dengan klasifikasi interpretasi sebagai berikut: 
Tabel 1. Interpretasi Persentasi Kuesioner

\begin{tabular}{|c|c|}
\hline Persentase & Kriteria \\
\hline $0-20 \%$ & Sangat lemah \\
\hline $21-40 \%$ & Lemah \\
\hline $41-60 \%$ & Cukup \\
\hline $61-80 \%$ & Kuat \\
\hline $81-100 \%$ & Sangat kuat \\
\hline
\end{tabular}

\section{HASIL DAN PEMBAHASAN}

\subsection{Profil Partisipasi Perempuan dalam Perekonomian Keluarga}

Perempuan di Kampung Pelangi tidak hanya berprofesi sebagai ibu rumah tangga, sebagian dari mereka merupakan penjual bunga di Pasar Kembang Kalisari. Keterlibatan perempuan pada sektor perekonomian di Kampung Pelangi Randusari meningkat setelah kawasan ini menjadi lokasi wisata di pusat kota. Diwadahi oleh PKK dan POKDARWIS, perempuan yang bermukim di Kampung Pelangi mulai membangun usaha rumah tangga dengan membuat souvenir atau kriya yang dapat dijual. Sebagian juga membuka usaha kelontong atau berjualan makanan dan minuman untuk pengunjung Kampung Pelangi Randusari.

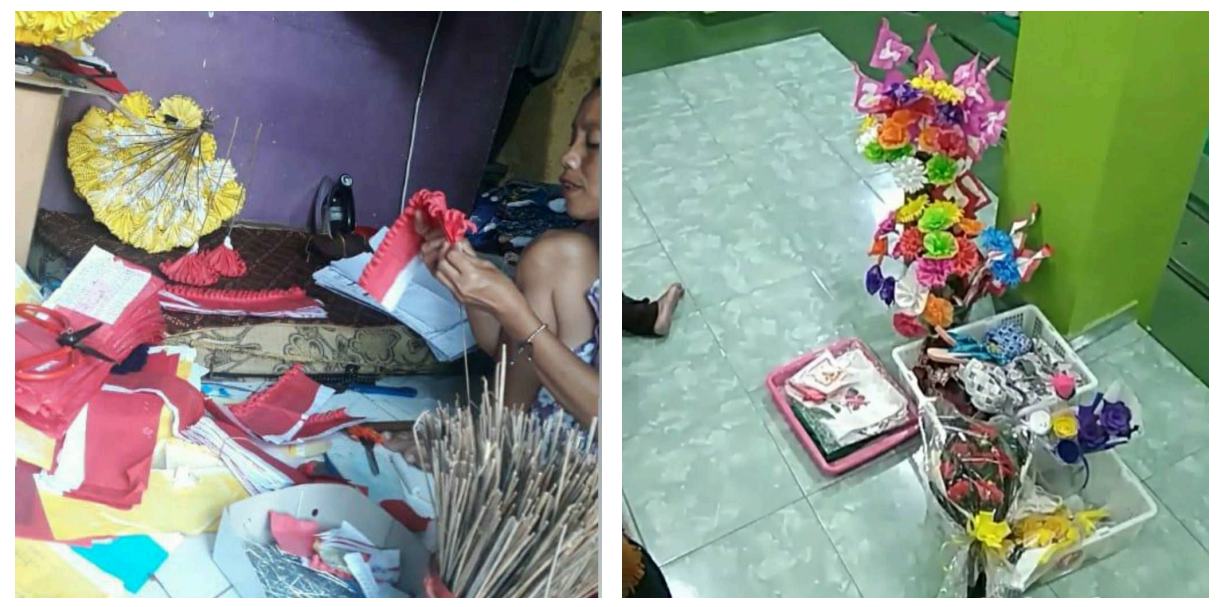

Gambar 1. Jenis Usaha Rumah Tangga Sumber: Dokumentasi Peneliti, 2020

Berdasarkan data pengabdian Komunitas Kepak Project tahun 2019, fenomena ini meningkatkan penghasilan penduduk setempat hingga mencapai Rp200.000 per hari hanya dengan berjualan minuman dan makanan ringan. Beberapa keluarga bahkan berpendapat, 
bahwa penghasilan meningkat hingga Rp600.000 per hari. Rata-rata perempuan atau istri yang bermukim di Kampun Pelangi Randusari masih dalam usia produktif, sehingga banyak keterampilan dan kreativitas yang dapat dikembangkan. Mata pencaharian yang dimiliki oleh para istri tersebut antara lain pedagang kelontong, pedagang bunga, pengrajin bunga kertas, pedagang makanan dan minuman, penjahit, penjual sayuran, olahan makanan, dan pengrajin pita gabus. Ketrampilan mereka kemudian diasah dengan adanya POKDARWIS yang mengadakan pelatihan untuk para istri.
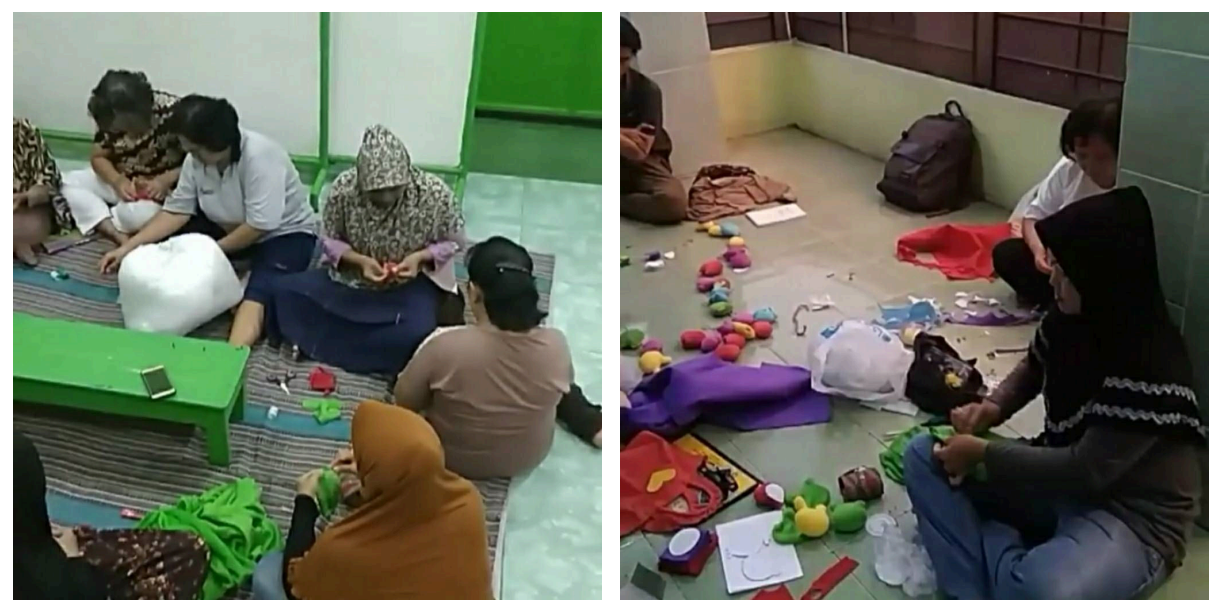

Gambar 2. Pelatihan Peningkatan Keterampilan Sumber: Dokumentasi Peneliti, 2020

Partisipasi perempuan dalam kegiatan ekonomi dilakukan dengan membuka usaha rumahan berupa kreasi bunga kertas, membuka toko kelontong, dan membuka usaha olahan makanan. Berdasarkan hasil wawancara yang dilakukan dengan Ketua RT 01, 02, dan 03 di RW 03 Kelurahan Randusari diketahui bahwa perempuan di Kampung Pelangi mampu mengerjakan 200-300 tangkai bunga kertas per harinya. Untuk dapat menghasilkan 1 ikat kembang kertas dibutuhkan 25 tangkai bunga kertas. Harga jual per ikat kembang kertas sebesar Rp30.000. Selain itu, perempuan di Kampung Pelangi memilki ketrampilan untuk membuat gladiola atau kreasi bunga kertas berbentuk pedang yang dapat digunakan untuk berbagai karangan bunga papan. Perempuan di Kampung Pelangi dapat membuat 400 lembar gladiol per minggunya yang dijual dengan harga Rp30.000-Rp75.000 per 100 lembar. Modal didapatkan melalui dana pribadi untuk dibelikan alat kriya, bahan pewarna makanan, dan 1 kerdus yang berisikan $10 \mathrm{~kg}$ kertas untuk dikreasikan. Kembang kertas dan gladiol tersebut dijual kepada kios-kios bunga di Pasar Kembang Kalisari untuk 
memenuhi permintaan berbagai kegiatan pernikahan hingga acara wisuda di Kota Semarang. Sistem pembayaran yang dilakukan kios di Pasar Kembang Kalisari dilakukan maksimal 3 setelah pemberian kreasi bunga kertas dan gladiol.
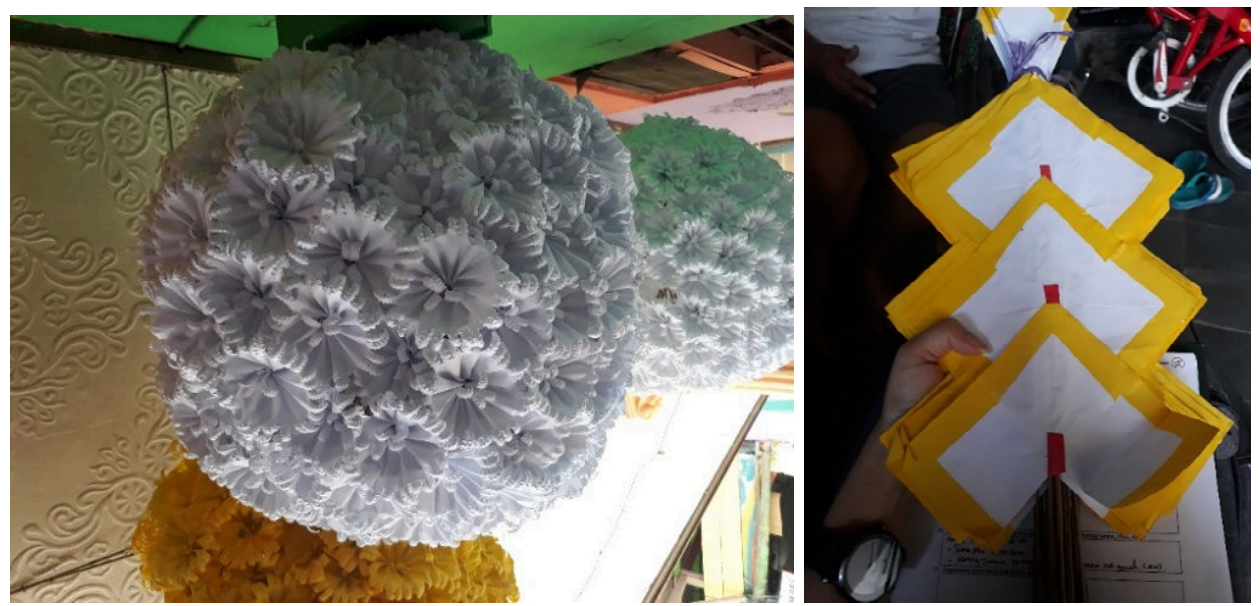

Gambar 3. Kreasi Bunga Kertas di Kampung Pelangi Randusari Sumber: Dokumentasi Peneliti, 2020

Menurut Usman (2015) tujuan dari pemberdayaan masyarakat melalui pendekatan bottom-up adalah perbaikan kondisi sosial dan ekonomi dengan sasaran masyarakat kategori miskin. Pendekatan bottom-up diindikasikan dengan pemberian kewenangan penuh pada desa untuk merumuskan hingga melaksanakan kegiatan pembangunan, dengan memposisikan pemerintah daerah sebagai fasilitator, pembina dan pengawas.

Pada penerapannya Pemerintah Kota Semarang memilih Kelurahan Randusari yang dahulunya dikenal sebagai salah satu kawasan kumuh perkotaan dengan jumlah penduduk miskin yang tinggi (BPS, 2015). Sejalan dengan literatur sebelumnya, Pemerintah Kota Semarang menyerahkan perumusan program pada tokoh desa dan masyarakat. Di saat bersamaan Pemerintah Kota Semarang berperan sebagai fasilitator dalam wadah diskusi, sebagai pembina pada kegiatan perbaikan fisik permukiman dan lingkungan tinggal Kelurahan Randusari, dan sebagai pengawas pada tiap kegiatan dengan bentuk kontrol pada tokoh desa. Selain itu, Pemerintah Kota Semarang juga berperan sebagai penyedia bantuan dana. Pada penerapannya, Pemerintah Kota Semarang terlebih dahulu melakukan sosialisasi terkait program Kampung Tematik sebagai alat pembangunan desa dan peningkatan kesejahteraan. Masyarakat, terutama perempuan, diberikan edukasi terkait peran dan fungsi yang dapat mereka ambil untuk membantu pencapaian tujuan program. 
Pemerintah Kota Semarang juga memberikan kesempatan dan akses bagi perempuan untuk dapat menyampaikan keluhan dan kebutuhan, memberikan masukan, hingga merumuskan program secara bertahap melalui pembentukan kelompok Sadar Wisata (Dawis). Selain itu, dilakukan pemberdayaan terhadap lembaga tingkat desa yang sudah ada, seperti PKK, dan mengaktifkan wadah perkumpulan perempuan, seperti arisan dan kumpul ibu-ibu, untuk dapat mendorong dan memberikan kepercayaan diri bagi perempuan untuk dapat berpartisipasi aktif pada program. Hasil wawancara yang dilakukan menyimpulkan bahwa terdapat beberapa langkah yang digunakan pemerintah untuk meningkatkan partisipasi perempuan pada ekonomi keluarga di Kampung Pelangi, yaitu:

1) Melakukan edukasi kepada perempuan untuk dapat memahami karakteristik, potensi diri, dan potensi lingkungan tinggal.

2) Membentuk kelompok atau organisasi tingkat desa yang dapat mengkoordinir kegiatan perempuan.

3) Memberdayakan keterampilan melalui pelatihan melalui kerjasama dengan akademisi dan NGO.

4) Pemberian modal dan sumber daya yang dapat mendorong pembentukan UMKM di Kampung Pelangi.

5) Membangun sikap mandiri pada ekonomi keluarga, sehingga dapat meningkatkan kesejahteraan keluarga.

\subsection{Bentuk Partisipasi Perempuan Pada Ekonomi Keluarga di Kampung Pelangi}

Pada penelitian ini, bentuk partisipasi uang diukur dengan jumlah pendapatan istri melalui usaha mandiri, bentuk partisipasi harta benda diukur dengan kepemilikan alat atau perkakas yang menunjang, dan bentuk partisipasi tenaga merupakan jumlah waktu yang digunakan istri untuk bekerja. Berdasarkan hasil olahan kuesioner, usaha untuk meningkatkan partisipasi perempuan pada ekonomi keluarga, menghasilkan sebanyak 25 perempuan atau $83 \%$ perempuan memiliki rata-rata pendapatan sebesar $\leq \mathrm{Rp} 1.499 .999$ per bulan. Sedangkan, rata-rata gabungan pendapatan suami dan istri adalah Rp1.500.000 Rp3.499.000 per bulan. Maka, disimpulkan bahwa pendapatan istri menyumbang hingga paling tinggi $50 \%$ dari gabungan pendapatan keluarga. Berdasarkan hasil penelitian didapat informasi bahwa sebanyak 50\% istri di Kampung Pelangi memiliki mata pencaharian sesudah diadakannya program kampung tematik. Sejumlah 93\% istri 
mendapatkan pelatihan peningkatan keterampilan dan kapasitas diri. Penelitian juga menemukan bahwa $60 \%$ istri di Kampung Pelangi mendapatkan dorongan berupa kesempatan untuk dapat berpartisipasi pada ekonomi keluarga.

Berdasarkan hasil analisis bentuk partisipasi perempuan pada ekonomi keluarga, dapat disimpulkan bahwa urutan bentuk partisipasi paling besar ada pada tenaga yang dimanifestasikan dalam bentuk waktu, bentuk partisipasi uang berupa pendapatan dari usaha rumah tangga, dan terakhir harta benda berupa alat dan perkakas. Selain itu, juga diperoleh informasi bahwa suami pada umumnya mendorong dan merasakan manfaat dari partisipasi perempuan pada ekonomi rumah tangga. Namun, kendala utama perempuan untuk berpartisipasi juga terdapat pada konflik alokasi waktu di sektor publik dan domestik. Hal ini diperkuat dengan tanggapan suami yang merasa bahwa kegiatan istri dalam ekonomi rumah tangga sedikit mengganggu urusan rumah tangga dan mengurus anak.

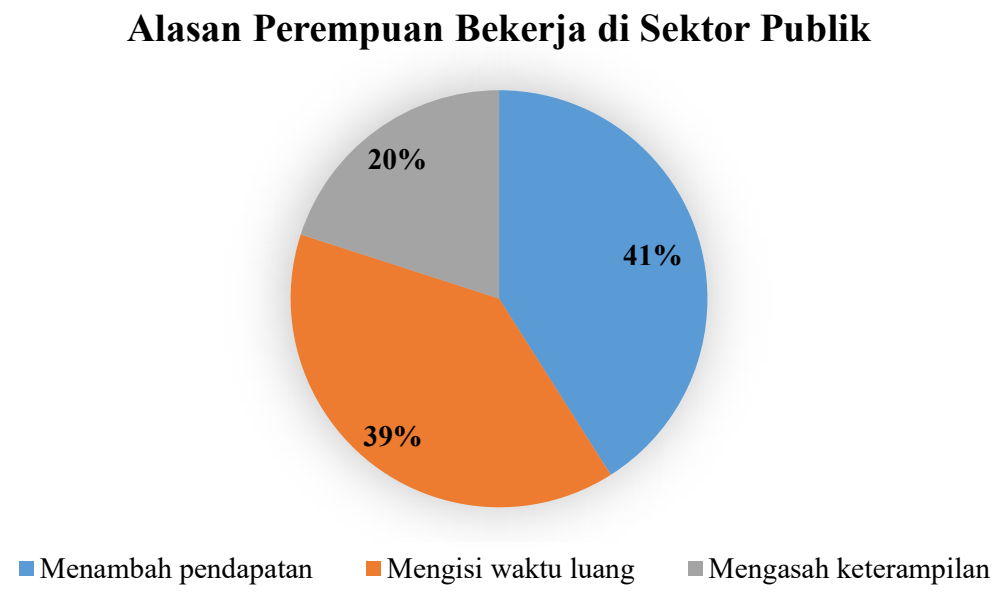

Gambar 4. Grafik Alasan Perempuan Bekerja di Sektor Publik Sumber: Analisis Peneliti, 2020

Peneliti menambahkan beberapa pertanyaan untuk mengetahui apa alasan perempuan berpartisipasi pada ekonomi keluarga. Sebanyak 41\% perempuan mengatakan bahwa usaha mereka dalam ekonomi keluarga dilakukan untuk menambah pendapatan keluarga agar dapat memenuhi kebutuhan keluarga. Alasan selanjutnya adalah untuk mengisi waktu luang yang dimiliki. Sebanyak 39\% perempuan menilai bahwa dibutuhkan kegiatan untuk mengurangi tingkat stres. Dengan adanya usaha rumah tangga, perempuan dapat bersosialisasi dalam perkumpulan guna meningkatkan usaha yang mereka miliki. Sebanyak $20 \%$ perempuan mengatakan bahwa keahlian atau keterampilan yang mereka 
miliki sebagai alasan untuk membuka usaha rumah tangga. Seluruh perempuan sebagai narasumber mengatakan bahwa saat ini penting untuk berpartisipasi pada ekonomi keluarga agar dapat memenuhi kebutuhan di masa kini dan yang akan datang.

\subsection{Faktor Partisipasi Perempuan Pada Ekonomi Keluarga Kampung Pelangi}

Faktor partisipasi perempuan dipengaruhi oleh alasan individu atau kelompok dalam memainkan peran pada program atau kebijakan (Rahmawati \& Sumarti, 2011). Tabel di bawah ini menjelaskan hasil olahan data faktor internal yang mempengaruhi partisipasi istri pada ekonomi keluarga.

Tabel 2. Persentase Faktor Partisipasi Perempuan Pada Ekonomi Keluarga

\begin{tabular}{|l|c|c|}
\hline Faktor Partisipasi & Persentase & Keterangan \\
\hline Kemauan & $68 \%$ & Kuat \\
\hline Kemampuan & $73 \%$ & Kuat \\
\hline Kesempatan & $60 \%$ & Cukup \\
\hline
\end{tabular}

Sumber: Analisis Peneliti, 2020

Deskripsi tabel di atas menunjukkan faktor partisipasi perempuan pada ekonomi keluarga di Kampung Pelangi. Faktor utama yaitu kemampuan merupakan keyakinan pada diri yang dituangkan dalam bentuk pikiran, tenaga, waktu, sarana, atau material lain yang menjadi potensi individu untuk berpartisipasi (Slamet, 2003). Hal tersebut didukung dengan pengadaan pelatihan sebagai proses pembelajaran untuk meningkatkan keterampilan dan pengembangan diri (Siagian, 2008). Berdasarkan hasil wawancara diketahui bahwa perempuan di Kampung Pelangi rutin mengadakan pelatihan kerajinan bunga dari kertas, pelatihan memasak, dan pelatihan membuat souvenir tiap satu bulan sekali. Selain itu, keterampilan kerajinan bunga kertas sudah dimiliki perempuan di Kampung Pelangi sebelum adanya program dari pemerintah kota. Hal ini disebabkan adanya Pasar Bunga Kalisari yang membutuhkan kerajinan bunga kertas, sehingga perempuan di Kampung Pelangi terbiasa memasok kebutuhan kerajinan bunga kertas tersebut.

Analisis terhadap faktor internal partisipasi perempuan pada ekonomi keluarga dipengaruhi oleh usaha pemerintah dan stakeholder terkait. Berikut merupakan grafik faktor internal dan keterkaitan dengan usaha pemerintah dalam meningkatkan partisipasi perempuan pada ekonomi keluarga di Kampung Pelangi: 
Gambar 5. Hubungan Faktor Internal dan Eksternal dalam Partisipasi Perempuan

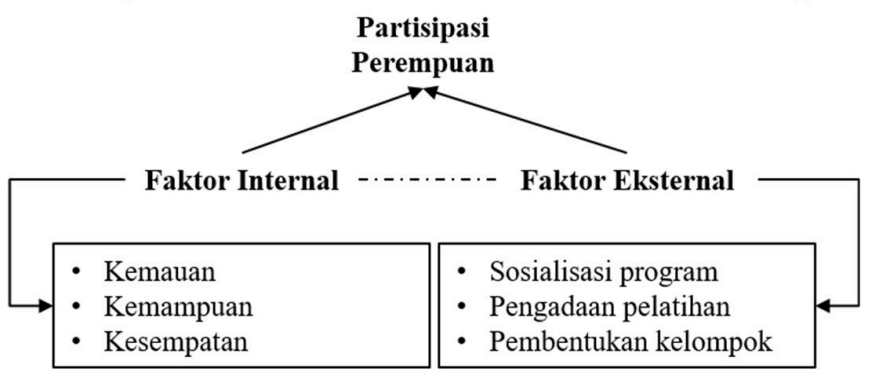

Sumber: Purwoko, 2007

Apabila dijabarkan dalam tabel, berikut merupakan hasil analisis tentang faktor paling mempengaruhi kegiatan partisipasi perempuan di Kampung Pelangi Randusari.

Tabel 3. Keterkaitan Faktor Internal dan Eksternal Partisipasi Perempuan Pada Ekonomi Keluarga

\begin{tabular}{|c|c|c|}
\hline Faktor Internal & Persentase & Faktor Eksternal \\
\hline Kemampuan & $\begin{array}{c}73 \% \\
\text { (Kuat) }\end{array}$ & $\begin{array}{l}\text { - Adanya peluang mata pencaharian pengrajin bunga } \\
\text { dipengaruhi oleh permintaan Pasar Bunga Kalisari. } \\
\text { - Adanya pelatihan keterampilan oleh Pemerintah Kota } \\
\text { yang dilakukan satu bulan satu kali. } \\
\text { - Pemberian modal usaha oleh Pemerintah Kota yang } \\
\text { dikelola oleh Dawis masing-masing RW. }\end{array}$ \\
\hline Kemauan & $\begin{array}{c}68 \% \\
\text { (Kuat) }\end{array}$ & $\begin{array}{l}\text { - Adanya sosialisasi Pemerintah Kota } \\
\text { memperkenalkan dan menyusun bersama program } \\
\text { berkaitan dengan kegiatan ekonomi keluarga. } \\
\text { - Adanya keterlibatan akademisi dan LSM untuk membantu } \\
\text { mencari solusi atas permasalahan bersama di Kampung } \\
\text { Pelangi. }\end{array}$ \\
\hline Kesempatan & $\begin{array}{c}60 \% \\
\text { (Cukup) }\end{array}$ & $\begin{array}{l}\text { - Pembentukan Pokdarwis masing-masing RW dengan } \\
\text { memisahkan kawasan atas (dekat pemakaman) dan bawah } \\
\text { (dekat sungai). } \\
\text { - Pengaktifan kembali PKK dan Karang Taruna untuk dapat } \\
\text { memberdayakan masyarakat. } \\
\text { - Peran aktif tokoh masyarakat agar penduduk dapat } \\
\text { memberdayakan keterampilan. }\end{array}$ \\
\hline
\end{tabular}

Sumber: Analisis Peneliti, 2020

Tabel tersebut menjelaskan bagaimana upaya dari berbagai stakeholder dapat meningkatkan faktor internal perempuan untuk berpartisipasi dalam ekonomi keluarga. Hasil penelitian juga menemukan adanya desakan internal bagi perempuan untuk berpartisipasi pada ekonomi keluarga. Desakan tersebut muncul dari alasan bekerja untuk menambah pendapatan keluarga dan meningkatkan kemampuan pemenuhan kebutuhan keluarga. Berdasarkan hasil kuesioner, diketahui bahwa desakan tersebut merupakan salah 
satu alasan $100 \%$ perempuan di Kampung Pelangi menyatakan bahwa perempuan perlu bekerja untuk membantu ekonomi keluarga.

\section{KESIMPULAN}

Artikel ini telah secara detail menjelaskan bentuk partisipasi perempuan pada ekonomi keluarga diakibatkan adanya faktor internal yang sebagian besar dipengaruhi oleh usaha pemerintah atau stakeholder terkait. Bentuk partisipasi perempuan pada ekonomi keluarga paling besar ada pada tenaga yang dimanifestasikan dalam bentuk waktu, selanjutnya bentuk partisipasi uang berupa pendapatan dari usaha rumah tangga, dan terakhir harta benda berupa alat dan perkakas. Partisipasi perempuan pada ekonomi keluarga merupakan bentuk aktualisasi diri yang didukung secara positif oleh suami. Faktor utama partisipasi perempuan pada ekonomi keluarga yaitu faktor kemampuan. Faktor kemampuan diakibatkan adanya usaha dari stakeholder untuk mengadakan pelatihan, pembentukan peluang usaha, dan pemberian modal usaha.

\section{DAFTAR PUSTAKA}

Aryani, Beti. (2017). Peran Perempuan dalam Membantu Ekonomi Keluarga di Desa Tanjung Setia Kecamatan Pesisir Selatan, Kabupaten Pesisir Barat. Repository Raden Intan: Lampung.

Aswiyati, I. (2016). Peran Wanita dalam Menunjang Perekonomian Rumah Tangga Keluarga Petani Tradisional untuk Penanggulangan Kemiskinan di Desa Kuwil Kecamatan Kalawat. Jurnal Holistik. Tahun IX, No. 17.

Badan Pusat Statistik . (2020, Juli 15). Berita Resmi Statistik No. 46/07/33/Th. XIV: KemiskinanProvinsi Jawa Tengah Maret 2020. Retrieved from jateng.bps.go.id: https://jateng.bps.go.id/pressrelease/2020/07/15/1225/persentase-penduduk--miskinmaret-2020-naik-menjadi-11-41-persen--dibanding-september-2019--yang-sebesar10-58-persen.html

Cahyaningrum, Putri. (2018). Pengembangan Wisata Kampung Pelangi Melalui Pemberdayaan Masyarakat di Kota Semarang. Digilib FISIP UNDIP: Semarang.

Deviyanti, D. 2013. Studi Tentang Partisipasi Masyarakat Dalam Pembangunan Di Kelurahan Karang Jati Kecamatan Balikpapan Tengah. Repository Unimul.

Freguja, Cristina, dkk. (2007). Women dan Economics: Household, enterprise, and decision-making bodies. Global Forum on Gender Statistics: Italy.

KEMENKO PMK. 2019. Optimalisasi Peran Perempuan dalam Pembangunan. Diakses melalui https://www.kemenkopmk.go.id/optimalisasi-peran-perempuan-dalampembangunan. Diakses pada 10 Juni 2020.

Mohyuddin, Anwaar. Women's Contribution in the Household Economy. European Academic Research, Vol II: Issue 7.

Puspitasari, Novi. (2013). Peran Gender, Kontribusi Ekonomi Perempuan, dan Kesejahteraan Keluarga Petani Holtikultura. Jurnal Kel. \& Kons: 10 -19. 
Rahmawati, \& Sumarti, T. (2011). Analisis Tingkat Partisipasi Peserta Program CSR Pemberdayaan Ekonomi PT. Arutmin Indonesia. Jurnal Transdisiplin Sosiologi, Komunikasi, Dan Ekologi Manusia, 325-338.

Ramdani, Aris Muhamad. (2015). Nilai-Nilai Kearifan Lokal Masyarakat Daerah Aliran Sungai (DAS) Cikapundung Bagian Hulu Dalam Usaha Pelestarian Sumber Daya Air. Universitas Pendidikan Indonesia: Bandung.

Siagian, Sondang P. (2008). Manajemen Sumber Daya Manusia (Edisi Pertama). Binapura Aksara.: Jakarta.

Slamet, M. (2003). Membentuk Pola Perilaku Manusia Pembangunan. IPB Press: Bogor.

Sugiyono. (2011). Metode Penelitian Kuantitatif, Kualitatif dan R\&D.CV Alfabeta: Bandung.

Suharto E. (2005). Membangun Masyarakat Memberdayakan Rakyat. PT Refika Aditama: Bandung.

Suroso, Hadi, Abdul Hakim dan Irwan Noor. (2014). Faktor-Faktor Yang Mempengaruhi Partisipasi Masyarakat dalam Perencanaan Pembangunan di Desa Banjaran Kecamatan Driyorejo, Kabupaten Gresik. Jurnal Wacana Vol. 17: 1.

Usman, Sunyoto. (2015). Pembangunan Pemberdayaan Masyarakat. Pustaka Pelajar: Yogyakarta. 